\title{
Melanistic Diversity in the Maritime Gartersnake, Thamnophis sirtalis pallidulus, in Nova Scotia, Canada
}

\author{
John GILhen ${ }^{1,2}$ and Fred W. SCOTT ${ }^{1}$ \\ ${ }^{1}$ Nova Scotia Museum of Natural History, 1747 Summer Street, Halifax, Nova Scotia B3H 3A6 Canada \\ ${ }^{2}$ Corresponding author: gilhenja@gov.ns.ca
}

Gilhen, John, and Fred W. Scott. 2014. Melanistic diversity in the Maritime Gartersnake, Thamnophis sirtalis pallidulus, in Nova Scotia, Canada. Canadian Field-Naturalist 128(1): 63-71.

We describe an unusual diversity of melanistic conditions in populations of the Maritime Gartersnake, Thamnophis sirtalis pallidulus, in Nova Scotia: pure melanism, melanism, nigrismus (predominantly melanistic), abundismus (mosaic melanism). This variability is widespread in Nova Scotia, and it includes coastal islands.

Key Words: Maritime Gartersnake; Thamnophis sirtalis pallidulus; pure melanism; melanism; nigrismus; predominantly melanistic; abundismus; mosaic melanism; coastal islands; Nova Scotia

\section{Introduction}

Rowell (2012) explained that melanism is a Mendelian recessive trait that is rare or absent in most Common Gartersnake (Thamnophis sirtalis) populations. Peters (1964) and Klauber (1972) provide definitions of melanism, nigrismus, and abundismus. Melanism is an unusual increase in the normal amount of black pigment within a particular individual as contrasted with other members of his species. Occasionally used to characterize a species in which all individuals are equally black. Nigrismus is a type of melanism in which the specimen is not completely black and shows a change in the elements of the basic pattern as a consequence of an increase in the size of the black portion of the pattern, making the specimen predominantly black. Abundismus is a mosaic type of melanism in which the specimen is not completely black but shows a change in the elements of the basic pattern as a consequence of an increase in the number of black spots or blotches in the non-black areas of the pattern.

We propose a fourth type of melanism: pure melanism. The pure melanistic condition is uniform black on the back and does not show a spotted pattern when the skin is spread. This is the main character which separates the pure melanistic condition from the melanistic condition.

All four melanistic conditions are variable in the Maritime Gartersnake, Thamnophis sirtalis pallidulus, and are widespread in specimens found on the mainland, on Cape Breton Island, and on two coastal islands in Nova Scotia (Figure 1). In general terms, these melanistic conditions in the Maritime Gartersnake in Nova Scotia can be defined as follows.

\section{Pure melanism}

Individuals are a uniform satiny black to bluish-black on the back (Figure 2), rarely with purplish gleam. The back will be lustrous in some lights when the snake is freshly shed. The top of the head, the underside of the trunk, and the tail are glossy black to bluish-black, (like the melanistic condition, see the photograph on the cover). The infralabials, chin shields, and gular scales, are enamel white, rarely bright pinkish-white. The white shades change abruptly to black or bluish-black on the first few anterior ventral scales, and the black or bluishblack extends to the tip of the tail. The skin between the scales is dull dark grey to bluish-grey throughout. Only 4 specimens of the Maritime Gartersnake are known to manifest the pure melanistic condition (Table 1). They do not show a Maritime Gartersnake spotted pattern when the skin is spread.

\section{Melanism}

Individuals are usually satiny black to bluish-black on the back (Figure 3 before shedding and the same snake, see cover, two days after shedding), rarely with a purplish gleam. The back is lustrous in some lights, particularly when the snake is freshly shed. The top of the head and the underside of the trunk and tail are glossy black to bluish-black. The infralabials, chin shields, and gular scales can be enamel white, bluish-white, yellowish-cream, light orange (on snakes from Georges Island, Halifax County), and rarely pinkish-white. In addition, some individuals have black spots or streaks on the side of the jaw, the chin, and the throat. These light colours change abruptly to the darker ventral colour on the first few anterior ventral scales. The skin between the scales can be bluish-white, light grey, or light yellowish-brown. When the skin is spread, large ellipsoid-shaped spots or smaller alternating spots, and dorsal stripe, if present, (characteristic of the Maritime Gartersnake spotted pattern), are revealed. This pattern, when the skin is spread, is the most distinguishing character which separates it from the pure melanistic morph.

Counting the 3 young from Wellington, there are 27 records of the melanistic condition (Table 2) in Nova 


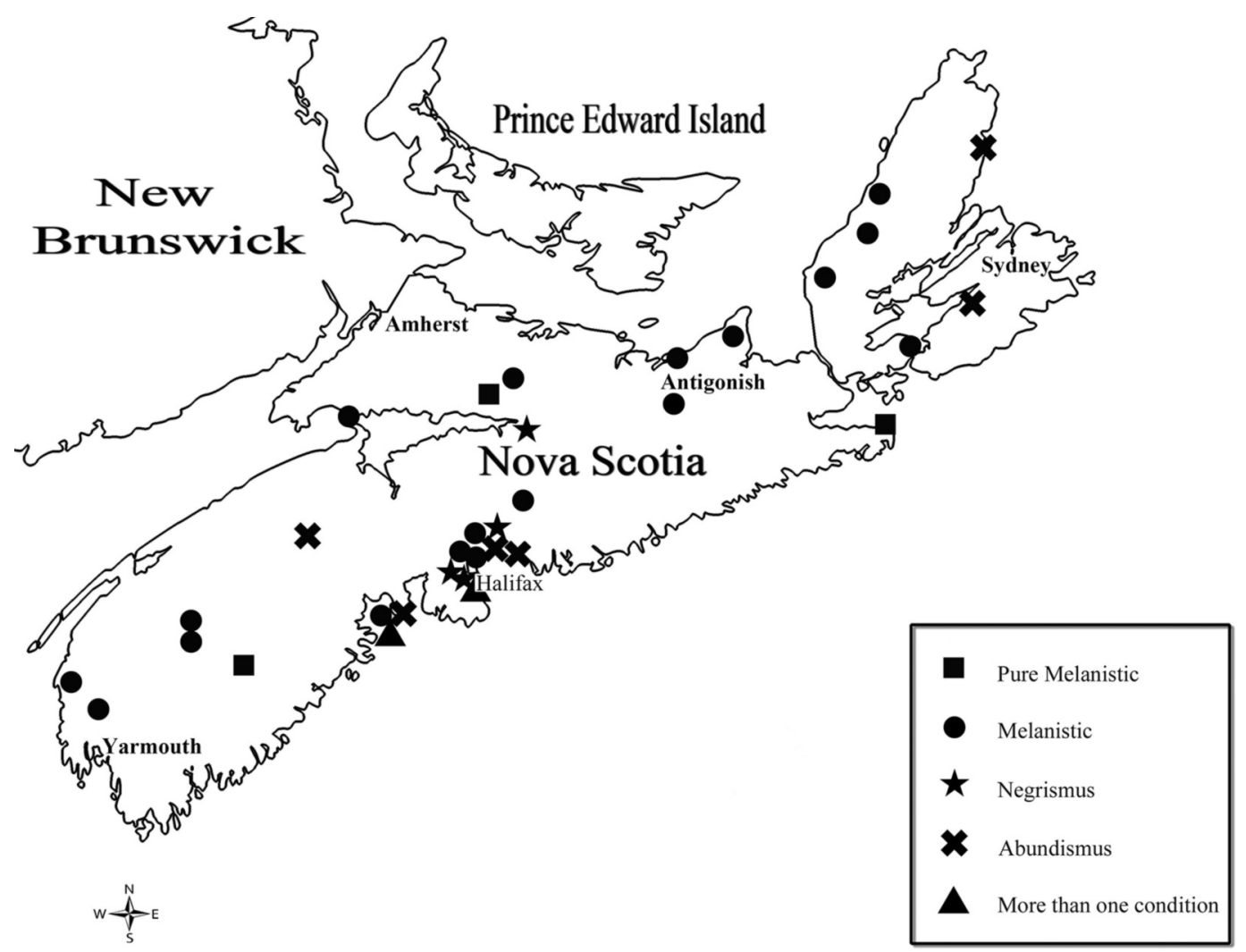

FIgURE 1. Distribution of the four melanistic conditions in the Maritime Gartersnake, Thamnophis sirtalis pallidulus, in Nova Scotia.

TABLE 1. Four pure melanistic Maritime Gartersnakes, (Thamnophis sirtalis pallidulus) from Nova Scotia, Canada, in chronological order.

\begin{tabular}{lllll}
\hline \hline Age & Sex & Locality & Date collected & Remarks \\
\hline $\begin{array}{l}\text { Adult } \\
\text { Adult }\end{array}$ & Female & Canso, Guysborough County & 5 October 1905 & Nova Scotia Museum, Piers no. 2937 \\
& Female & Lake Rossignal,Queens County & 21 October 1970 & $\begin{array}{l}\text { Nova Scotia Museum970-Z-400-1 } \\
\text { (Figure 2) }\end{array}$ \\
$\begin{array}{llll}\text { Adult } \\
\text { Adult }\end{array}$ & $\begin{array}{l}\text { Female } \\
\text { Female }\end{array}$ & $\begin{array}{l}\text { Londonderry,Colchester County } \\
\text { Big Tancook Island, Lunenburg County }\end{array}$ & $\begin{array}{l}\text { 24 May 1980 August 2013 } \\
\text { 18 }\end{array}$ & $\begin{array}{l}\text { Anomaly. Brown labials, black ventral } \\
\text { scales, and grey subcaudals (Figure 7) }\end{array}$ \\
\hline \hline
\end{tabular}

Scotia; 11 of these reported observations were made from a distance and do not include a description of the underside of the body or tail.

Nigrismus or predominantly black

This is a type of melanism in which the individual looks uniform black from a distance and up close it is predominantly black. The spotted pattern, and dorsal stripe, when present, of a Maritime Gartersnake are black and the remaining ground colour is a mosaic of blackish clove-brown with scattered white scales (Gilhen 2000) (Figure 4). This morph is dark steel grey "plumbeous" to grey-black on the underside of the trunk and the tail (Figure 5). The underside of the tail of one individual was blackish clove-brown. The infralabials, chin shields, and gular scales may be bluishwhite, or yellowish-cream to orange-cream, and may be freckled with grey. There are only four observations of the nigrismus or predominantly black condition in Nova Scotia (Table 3).

\section{Abundismus or mosaic}

In these Individuals, the normal spotted pattern is invaded by dark grey-black to black spots and/or blotch- 


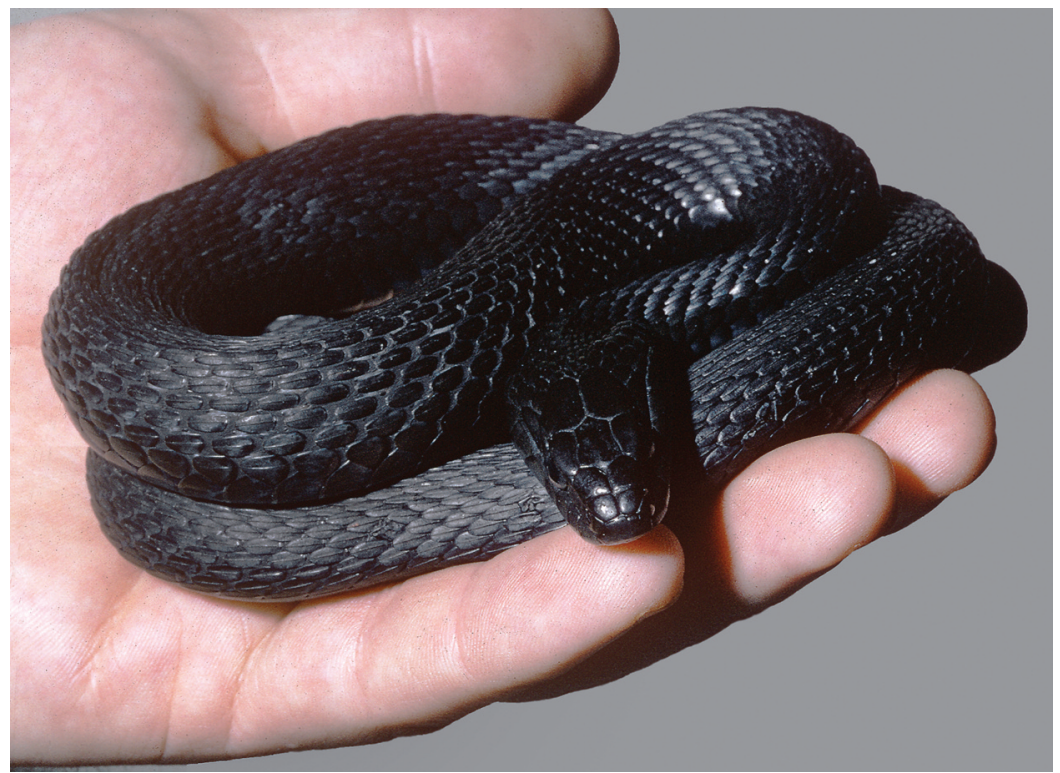

FIGURE 2. Pure melanistic Maritime Gartersnake, Thamnophis sirtalis pallidulus, from Lake Rossignol, Queens County, Nova Scotia, captured on 21 October 1970, by James Harding. Photo: R. Merrick.

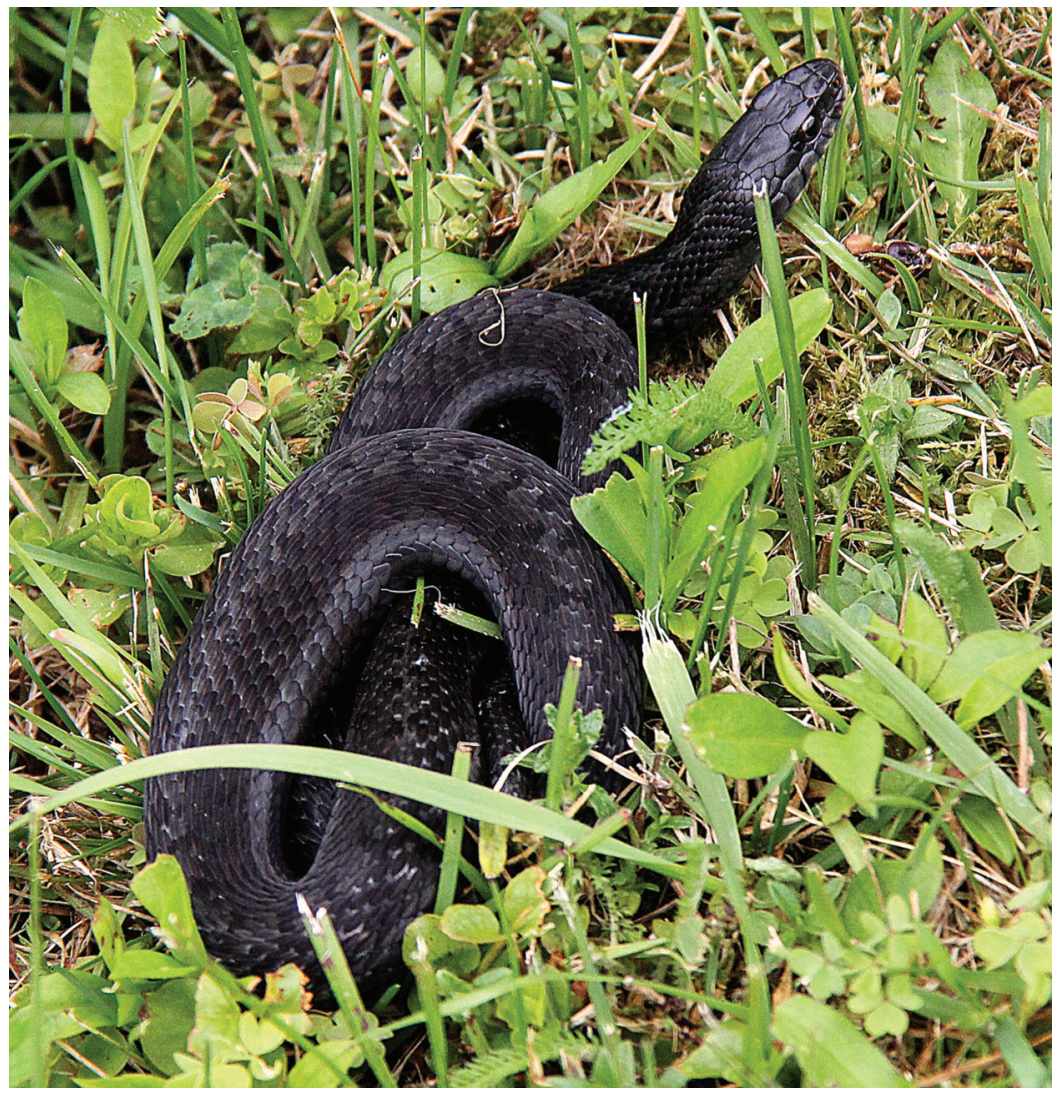

FIgURE 3. Melanistic Maritime Gartersnake, Thamnophis sirtalis pallidulus, from Big Tancook Island, Mahone Bay, Lunenburg County, Nova Scotia, captured on 7 May 2012 (before it shed its skin). Photo: H. Dionne. 
TABLE 2. Twenty- seven melanistic Maritime Gartersnakes (Thamnophis sirtalis pallidulus) from Nova Scotia, Canada, in chronological order.

\begin{tabular}{|c|c|c|c|c|}
\hline$\overline{\text { Age }}$ & Sex & Locality & Date collected & Remarks \\
\hline Unknown & Unknown & McNabs Island, Halifax County & 13 May 1929 & $\begin{array}{l}\text { Nova Scotia Museum no. 6519. "from its } \\
\text { colour it would be mistaken for a Black } \\
\text { Snake (Coluber constrictor)" }\end{array}$ \\
\hline Adult & Female & Fletcher 's Lake, Halifax County & 15 July 1962 & Sight record \\
\hline Adult & Unknown & Jacques Landing, Queens County & 16 August 1971 & $\begin{array}{l}\text { National Museum of Canada 13674. Park } \\
\text { highway road kill. }\end{array}$ \\
\hline Adult & Female & George 's Island, Halifax County & 4 July & Sight record \\
\hline dult & Female & George 's Island, Halifax County & $23 \mathrm{~J}$ & Sight record $\mathrm{n}$ \\
\hline Adult & Female & George 's Island, Halifax County & $23 \mathrm{~J}$ & $\begin{array}{l}\text { Sight record no. 2. Dark brownish-black } \\
\text { individual }\end{array}$ \\
\hline Adult & Male & George 's Island, Halifax County & 10 Augu & $\begin{array}{l}\text { Anomaly. Individual had Yellow dorsal stripe } \\
\text { anteriorly (Figure } 8 \text { ) }\end{array}$ \\
\hline 3 Young & Unknown & Wellington, Yarmouth County & 27 June & $\begin{array}{l}\text { F. R. Cook field numbers } 18758,18762 \text { and } \\
\text { stillborn } 18771\end{array}$ \\
\hline Inknown & Unknown & Lull & 16 & Nova Scotia Herpetological Atlas no. 3679 \\
\hline Unknown & Unknown & Upper Margaree, Inverness County & $10 \mathrm{Ju}$ & Nova Scotia Herpetological Atlas no. 10072 \\
\hline Unknown & Unknown & Margaree Forks, Inverness County & $10 \mathrm{~J}$ & ological Atlas no. 11900 \\
\hline Unknown & Unknown & Margaree Forks, Inverness County & $11 \mathrm{~J}$ & ological Atlas no. 10073 \\
\hline Unknown & Unknown & Clark Lake, Colchester County & $25 \mathrm{Ju}$ & Nova Scotia Herpetological Atlas no. 4352 \\
\hline Unknown & Unknown & Ponds, Pictou County & gust 2000 & Nova Scotia Herpetological Atlas no. 4883 \\
\hline Adult & Female & Dilligent River, Cumberland County & 3 July 2002 & Nova Scotia Herpetological Atlas no. 9196 \\
\hline Unknown & Unknown & Timberlea, Halifax County & Aug & Remains of house cat kill \\
\hline Unknown & Unknown & Iville, Richmond County & per 2002 & Nova Scotia Herpetological Atlas no. 10000 \\
\hline Adult & Female & Fairmont Road, Antigonish County & 9 Jun & Nova Scotia Herpetological Atlas no. 10451 \\
\hline Adult & Female & Grafton Lake, Queens County & $10 \mathrm{~J}$ & Sight record. Individual had bluish stripes \\
\hline Unknown & Unknown & County & $6 \mathrm{Ju}$ & Sight \\
\hline Adult & Female & Dilligent River, Cumberland County & 12 August 2004 & Nova Scotia Muse \\
\hline Adult & Female & Argyle Sound, Yarmouth County & Summer 2004 & Nova Scotia Museum catalogue no. 55593 \\
\hline Adult & Female & Garden of Eden, Pictou County & 4 July 2008 & $\begin{array}{l}\text { Sight record. Individual near shedding, } \\
\text { blue eyes }\end{array}$ \\
\hline Adult & Female & Dis tain & & Individual has bl \\
\hline Adult & Female & Lake Doucette, Digby County & 30 September 2012 & Nova Scotia Museum catalogue no. 55587 \\
\hline
\end{tabular}

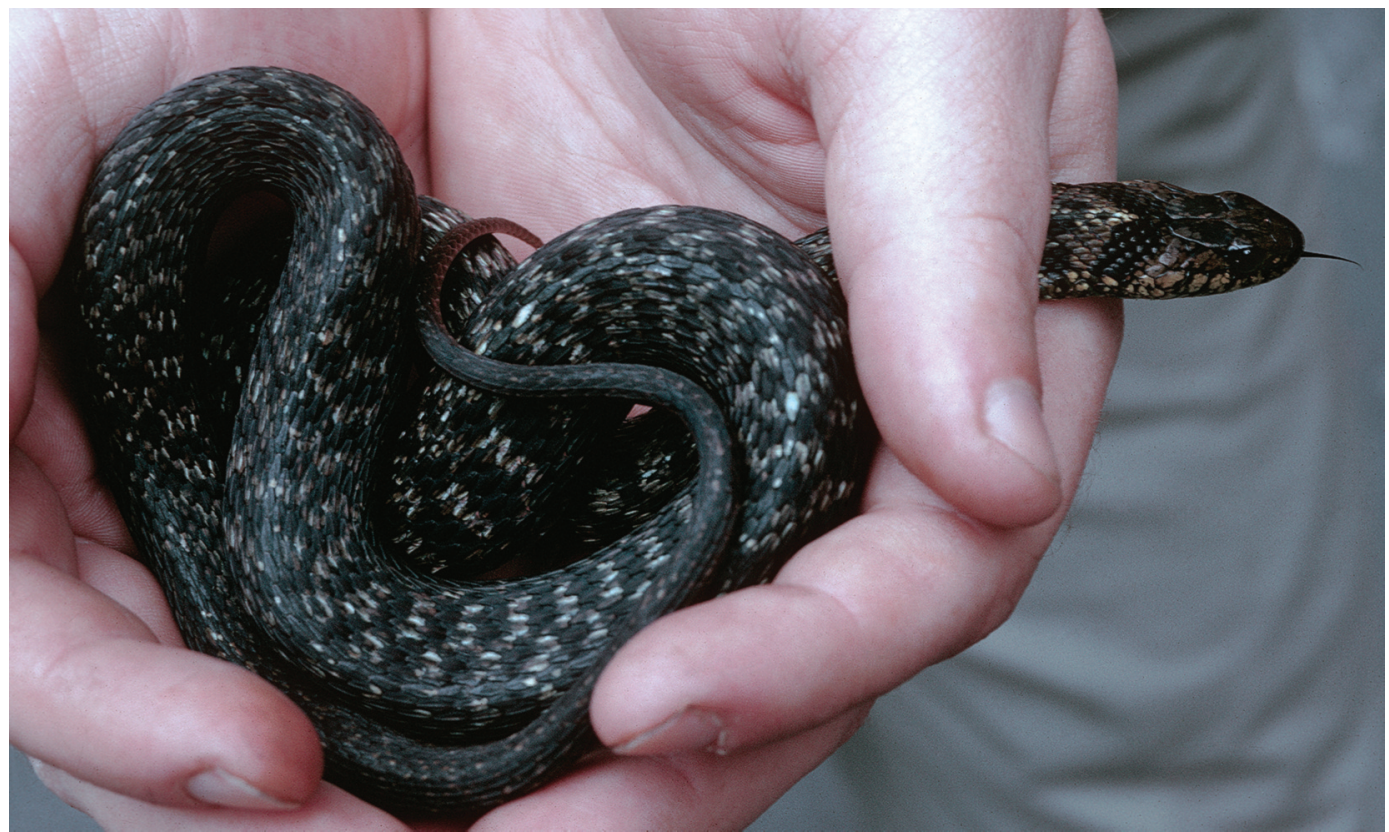

FIGURE 4. Dorsal view of nigrismus Maritime Gartersnake, Thamnophis sirtalis pallidulus, from McCabe Lake, Halifax County, Nova Scotia, captured on 24 June 1969. See also Figure 5. Photo: J. Gilhen. 


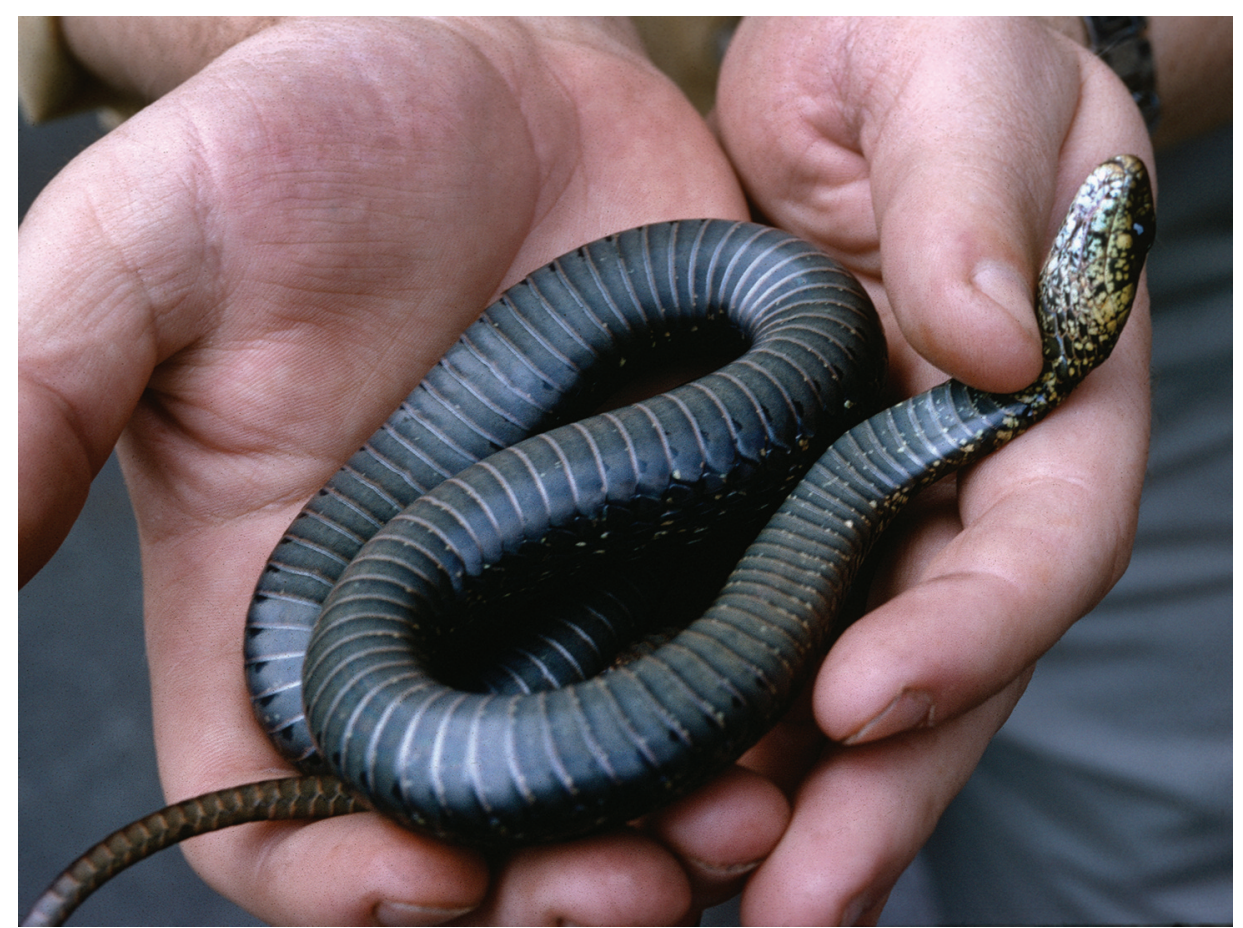

FigURE 5. Ventral view of the nigrismus Maritime Gartersnake, Thamnophis sirtalis pallidulus, shown in Figure 4. Photo: J. Gilhen.

es (Figure 6). The spots may be small, and involve only a few scales on one side, may be large and invasive of the dorsal spotted pattern and stripe, or may involve just the underside of the trunk and tail. The remaining ground colour or pattern is as variable as any Mar- itime Gartersnake in Nova Scotia. There are 9 records of the abundismus condition (Table 4). Abundismus individuals are often referred to in Nova Scotia as partmelanistic.

TABLE 3. Four nigrismus Maritime Gartersnakes (Thamnophis sirtalis pallidulus) from Nova Scotia, Canada, in chronological order.

\begin{tabular}{lllll}
\hline \hline Age & Sex & Locality & Date collected & Remarks \\
\hline Adult & Unknown & Paddy Lonis Brook, Halifax County & 29 April 1918 & Nova Scotia Museum catalogue no. 4604 \\
Adult & Female & Withrod Lake, Halifax County & 6 May 1934 & Nova Scotia Museum catalogue no. 7783 \\
Unknown & Unknown & Mill Brook, Colchester County & 7 August 1935 & Nova Scotia Museum Catalogue no. 8224 \\
Adult & Female & McCabe Lake, Halifax County & 24 June 1969 & $\begin{array}{c}\text { Canadian Museum of Nature Amphibians } \\
\text { and Reptiles no.12153 (Figures 4 and 5) }\end{array}$ \\
\hline \hline
\end{tabular}

TABle 4. Nine abundismus Maritime Gartersnakes (Thamnophis sirtalis pallidulus) from Nova Scotia, Canada, in chronological order.

\begin{tabular}{|c|c|c|c|c|}
\hline$\overline{\text { Age }}$ & Sex & Locality & Date collected & Remarks \\
\hline$\overline{\text { Adult }}$ & Male & Tomahawk Lake, Halifax County & 5 July 1970 & Site record \\
\hline Unknown & Unknown & Big Pond, Cape Breton County & 17 August 1977 & $\begin{array}{l}\text { National Museums of Canada } \\
\text { NMCAR25368 }\end{array}$ \\
\hline Adult & Male & George 's Island, Halifax County & 26 May 1989 & Sight record no. 1 (see Figure 6) \\
\hline Adult & Male & Georges Island, Halifax County & 26 May 1989 & Sight record no. 2 \\
\hline Adult & Male & George's Island, Halifax County & 14 April 1992 & Sight record \\
\hline Adult & Male & George's Island, Halifax County & 11 May 1992 & Sight record \\
\hline Adult & Male & South Ingonish beach, Victoria County & 5 September 1996 & Nova Scotia Museum 55056 \\
\hline Adult & Male & Big Tancook Island, Lunenburg County & 24 May 2003 & Sight record \\
\hline Adult & Male & Mack Lake, Kings County & 23 August 2003 & Nova Scotia Museum 55592 \\
\hline
\end{tabular}




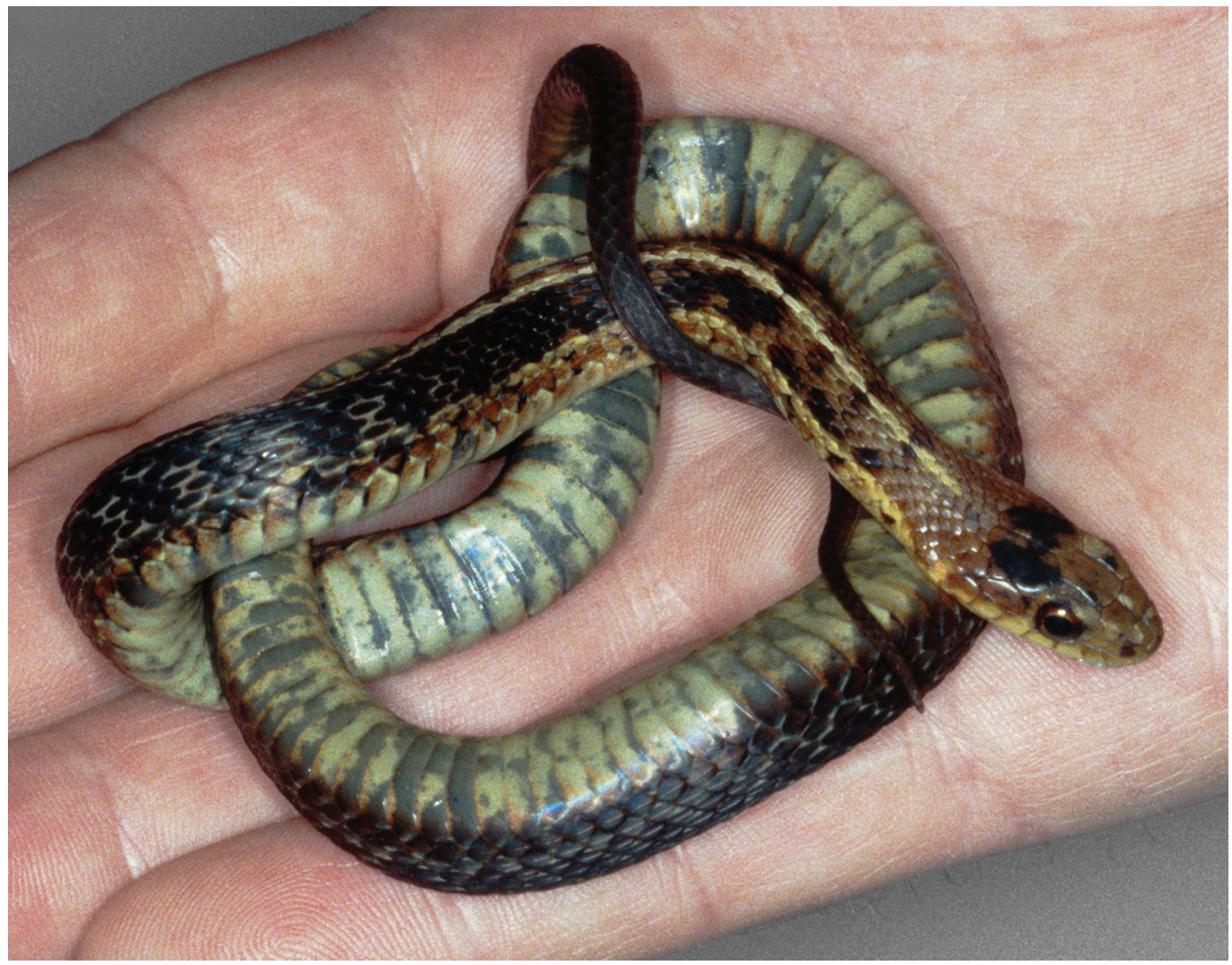

FIgURE 6. Abundismus Maritime Gartersnake, Thamnophis sirtalis pallidulus, from Georges Island, Halifax Harbour, Halifax County, Nova Scotia, captured on 26 May 1989. Photo: J. Gilhen.

\section{Discussion}

For almost a century and a half, there have been published and oral reports of black snakes from Nova Scotia, New Brunswick, and Prince Edward Island (Bleakney 1958). John Matthew Jones (1865) published the first list of amphibians and reptiles of Nova Scotia and he included the Black Snake, Coluber constrictor (i.e., North American Racer). Gilpin (1875) also gives an account of the Black Snake. These reports of the Black Snake, $C$. constrictor, are believed to be in error and actually can be attributed to the melanistic morph of the Maritime Gartersnake, as indicated by Harry Piers (Gilhen 2000) and mentioned by Bleakney (1958), Cook (1967), and Gilhen (1984). The North American Racer and North American gartersnakes (Thamnophis $s p p$.) are easily distinguished from one another by the scales on their back. The North American Racer has smooth dorsal scales and North American gartersnakes have strongly keeled scales.

The 4 melanistic conditions described above are uncommon in Nova Scotia but widespread. The ratio of melanistic individuals to four other recognized colour patterns in wild populations in Nova Scotia is not known. Only Georges Island, Halifax County, was sur- veyed specifically for Maritime Gartersnakes (Barnes et al. 2006). Between May and October 1993, a total of 391 Maritime Gartersnakes were marked on this 5-ha drumlin in Halifax Harbour. Barnes et al. (2006) state, "Rarely were individuals melanistic (solid black) or partially melanistic (five individuals)."

Over 100 Maritime Gartersnakes have been observed on Big Tancook Island by JG but only 3 individuals - one pure melanistic anomaly, one melanistic, and one abundismus were observed and photographed. We have kept 6 melanistic females from various localities until they gave birth, but they did not produce melanistic young. We have observed more than 20 non-melanistic females from various localities in Nova Scotia give birth, and none of their young were melanistic. Also, we have not found melanistic young in the field. However, Francis R. Cook collected two non-melanistic pregnant females from Wellington, Yarmouth County, one on 27 June 1995 and the second on 2 July 1995. Both females gave birth in captivity. The female from 27 June, gave birth to 16 young ( 3 melanistic and 13 non-melanistic). The female from 2 July gave birth to 13 normal young. During annual visits from 1963 to 1995 to the former Frank Crosby farm at Wellington, 
Francis R. Cook and Joyce Cook never saw a melanistic Maritime Gartersnake. Also, Joyce Cook lived there from 1948 to 1958 and did not see a melanistic snake, nor were any noted by her parents or two brothers.

Melanism is more common in the Eastern Gartersnake, Thamnophis sirtalis sirtalis. Rowell (2012) provides a table (Table 24.1) listing the incidence of melanism reported at locations in southern Ontario, particularly on islands of western Lake Erie and at nearby mainland locations. The incidence varied from $6.4 \%$ at Point Pelee to $12 \%-59 \%$ at Point Pelee Island, East Sister Island, and Middle Island, and 24\%-51.2 \% at Long Point.

\section{Pure melanistic}

The first recorded observation of pure melanism in a Maritime Gartersnake is by Harry Piers (Accession Book No. 1, Nova Scotia Museum no. 2937). He stated, "Melanistic variety of Common Garter Snake, All Saints Rectory grounds, Canso, Guysborough County, by Rev. R. M. Leigh's man on 5 October 1905". Under Remarks he stated "Colour. - Back black, with no sign whatever, in any light, of blotches or stripes, etc.; underside of head white; belly slate-coloured, the under plates (belly \& tail) narrowly margined with lighter. Ventral plates with a black spot on outer margin, near beginning of dorsal scales, thus being almost concealed by the next ventral plate."

A large female from Londonderry was most unusual in that it was black with a distinct purplish lustre. The infralabial scales, chin shields, gular scales, and first few ventral scales were glossy pinkish-white and the remaining underside was grey-black with a pinkish lustre. The large female from Big Tancook Island was different and unusual in that the supra-labials and neck were brown fading to yellowish-cream on the infralabials, chin shields, gular scales, and first few ventral scales. This snake had a light lateral stripe on both sides anteriorly. The belly was black nearly to the anal plate and then changed abruptly to grey to the tip of the tail (Figure 7). It resembled mostly the pure melanistic condition. When the skin was spread, a Maritime Gartersnake spotted pattern was not revealed.

\section{Melanistic}

The first recorded observation of melanism in a Maritime Gartersnake is by Harry Piers (Accession Book No. 3, Nova Scotia Museum no. 6519). He recorded a

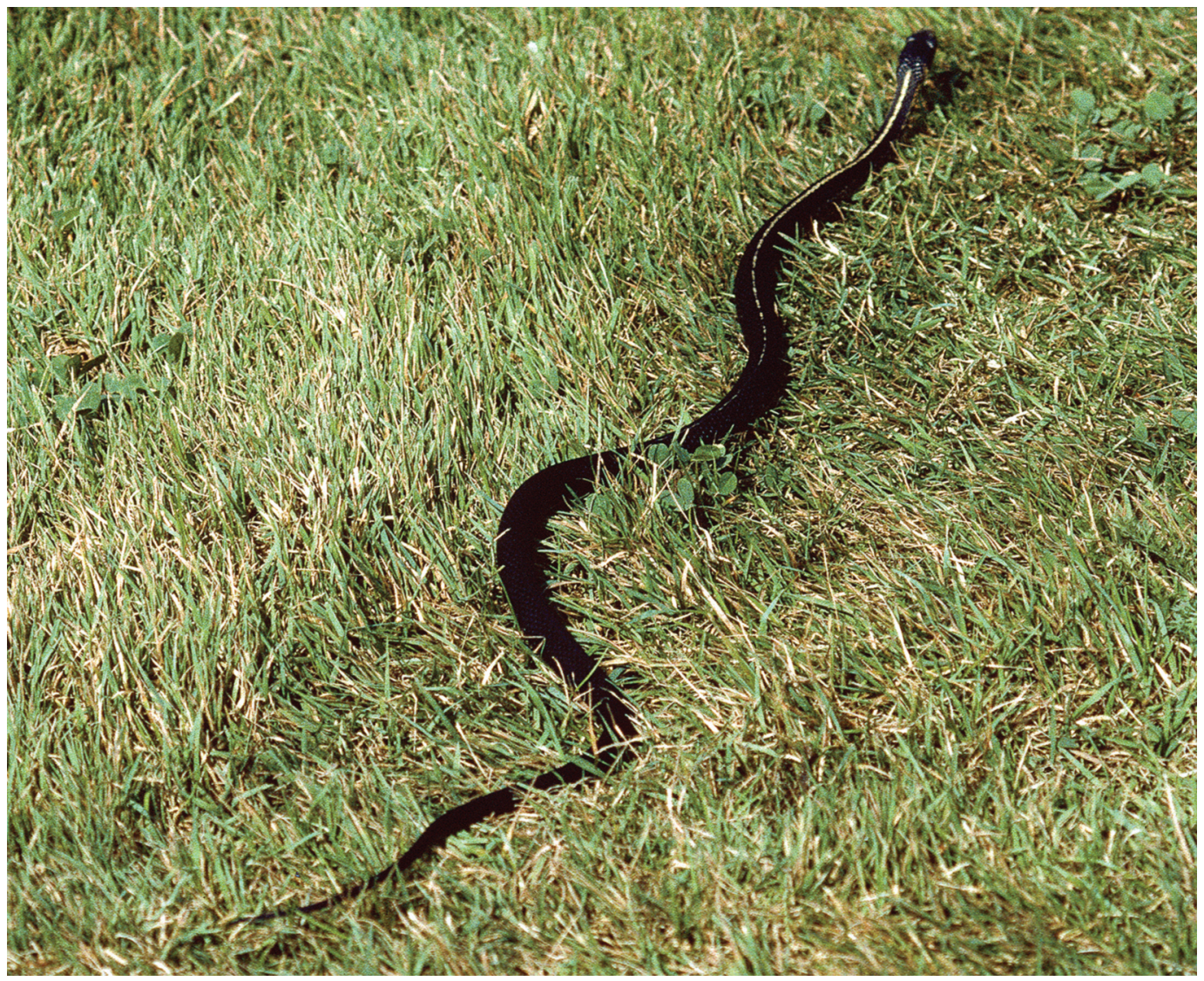

FIGURE 7. Adult male melanistic Maritime Gartersnake, Thamnophis sirtalis pallidulus, anomaly with light yellow anterior dorsal stripe from Georges Island, Halifax County, Nova Scotia, captured on 10 August 1992. Photo: J. Gilhen. 
"Striped Garter Snake ABNORMAL MELANISTIC INDIVIDUAL!!" from McNab's Island, Halifax Harbour, Halifax County, captured on 13 May 1929 by Joseph Perrin. "From its colour it would be mistaken for a Black Snake (Coluber constrictor)" (i.e., North American Racer). This may be the same variation of melanism exhibited by a female from Grafton Lake, Queens County, on 10 July 2003 and a female from Big Tancook Island, Lunenburg County, on 3 October 2011. Both females had blue-black dorsal and lateral stripes.

Of the 27 Maritime Gartersnakes reported here as melanistic, 9 were reported in the Nova Scotia Herpetological Atlas (NSHA). Since a description and/or image was not given, the Nova Scotia Herpetological Atlas number for each one is provided in Table 2.

The underside of the snake from Garden of Eden was not recorded and its blue eyes indicate it was about to shed. Two rare variations and one anomaly were found in the melanistic condition on Georges Island. One individual was dark brownish-black with orange at the corner of the mouth fading to yellowish-white on the chin and extending onto the first few ventral scales. Another snake from Georges Island was similar to a large pure melanistic female from Londonderry in that it was black with a distinct purplish gleam (Barnes et al. 2006.). The chin and first few ventral scales were glossy pinkishwhite and the remaining underside was dark pinkishgrey. One snake from Timberlea, Halifax County, was dark blueberry-blue on the back. The underside of the trunk was bluish-black. The sides of the head were blue fading to bluish-white on the chin shields. One adult male anomaly had a light yellow dorsal stripe anteriorly (Figure 8).

\section{Nigrismus}

The first recorded observation of nigrismus in a Maritime Gartersnake is also by Harry Piers (Accession Book No. 2, Nova Scotia Museum no. 4604). He recorded a striped garter snake, with melanistic tendency from Paddy Lonis Brook, one mile SSE of Enfield, Halifax County, on 29 April 1918. His detailed account of the colour is as follows: "Colour from fresh specimen. General colour very dark; stripes moderately plain (on anterior parts; spots very obscure owing to dark colour of back. Top of head and back blackish, Clove-Brown. Upper labials and lower part of snout plate (rostral) Buff. Iris, brown. Dorsal stripe (on dorsal row of scales and part of row on each side of it), dirty white; plainest for about 5 inches back of snout, and becoming lost about $12 \frac{1}{2}$ inches behind snout (that is, a little more than half-way of length). The stripe is broken for a couple of inches behind the head by the connection across it of 5 of the dark spots on each side of it. Lateral stripe on parts of $2^{\text {nd }}$ and $3^{\text {rd }}$ rows of scales pale olive-buff, plainest for about 5 inches behind snout, not so evident or so light as the dorsal stripe, and becoming lost about

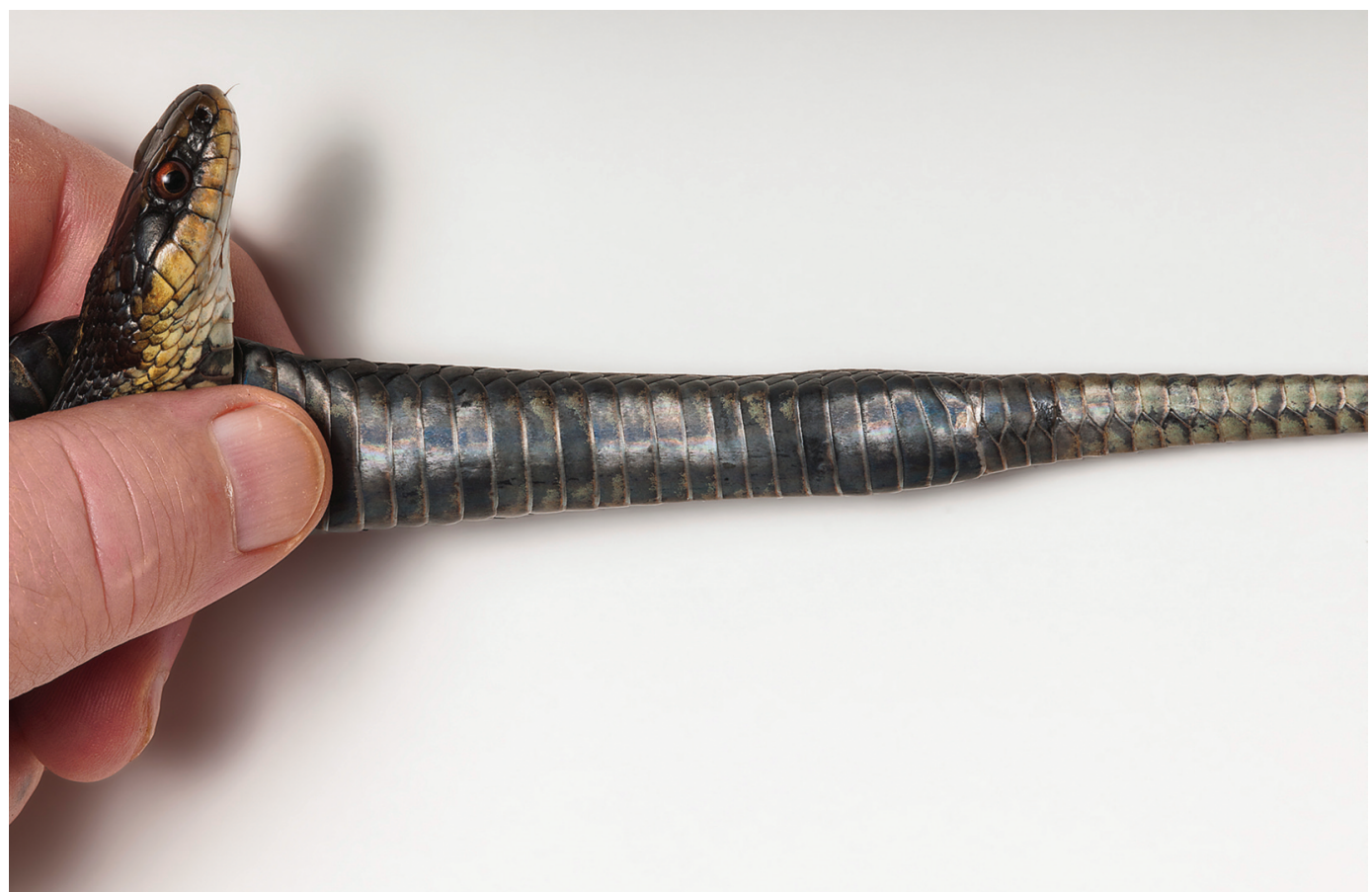

FIGURE 8. Pure melanistic Maritime Gartesnake, Thamnophis sirtalios pallidulus, anomaly with yellowish-brown supralabials fading to yellowish-white on underside of head and with blackish ventral scales and greyish subcaudal scales, from Big Tancook Island, Lunenburg County, Nova Scotia, captured on 18 August 2013. Photo: R. Lloyd. 
anus (about 17 inches from snout). Two rows of obscure black spots, the inner row about .10 inch diameter each spot, the outer row about 15 inch diameter each spot, arranged alternately (zig-zag fashion) on each side of dorsal stripe (that is between dorsal stripe and lateral stripe); these spots somewhat noticeable for 4 or 5 inches behind snout, but soon become lost in the general blackish colour of upper parts. Underside of head, bluish-white. Belly and underside of tail plumbous, the abdominal plates each with a black spot on the front lateral part. "

\section{Abundismus}

Abundismus or the mosaic condition is extremely variable. All 9 individuals recorded differed in the amount of black pigment. The spots can be small and involve only a few scales, large patches, or extensive grey-black areas, particularly on the posterior half of the body and tail, and the spots or areas invade or cover the normal spotted pattern and stripes (Figure 6).

\section{Acknowledgements}

We thank Francis R. Cook, Curator Emeritus and Research Associate, Canadian Museum of Nature, for his encouragement, and for prodding JG over many years to complete the manuscript. Dr. Cook and Andrew Hebda, Curator of Zoology, Nova Scotia Museum of Natural History, pre-reviewed and made useful comments on the manuscript. We are grateful to the following persons who either collected or provided reports of Nova Scotia Maritime Gartersnakes in a melanistic condition: David Baker, Joseph Baker, Suzanne Barnes, Francis R. Cook, James Callaghan, Gary Corbett, Stan Corbett, Albert d'Entremont, Hillary Dionne, Gert Ewelt (Nova Scotia Herpetological Atlas no. 4883), Calvin Fraser, Karen Gilhen, Michael Gilhen, David Gordon, May Goring, Ross Hall (Nova Scotia Herpetological Atlas no. 4352), Anne-Belle Hamilton, James Harding, David E. Harris, Peter Hope, Andrew Kennedy, Randy Lauff, Earl Luffman, George MacInnis, Norman Maloney, Mike McCabe, Ronald Merrick, John Mills (Nova Scotia Herpetological Atlas nos. 10072, 10073, and 11900), Dana Pierce, Russell Rogerson, and Wayne F. Weller. We thank Jeffrey Rowell for permission to cite his privately printed book on the snakes of Ontario.
Roger Lloyd, photographer, Nova Scotia Museum, developed digital images of all melanistic Maritime Gartersnakes from original colour transparencies and pictures taken by Ronald Merrick, JG, and Hillary Dione. The cover image is by Roger Lloyd. We thank naturalists Graham Caswell, Mary MacDonald, and Heather McKinnon for the professional care of the live Maritime Gartersnake display in the Netukulimk Gallery, giving us ample opportunity to study and photograph Maritime Gartersnakes in melanistic conditions. Kim Franklin, administrative assistant, and Roger Lloyd assisted in the development of Tables 1-4.

\section{Literature Cited}

Barnes, S. M., C. M. Dubesky, and T. B. Herman. 2006. Ecology and morphology of Thamnophis sirtalis pallidulus (Maritime Garter Snake) on Georges Island, Nova Scotia. Northeastern Naturalist 13(1): 73-82.

Bleakney, J. S. 1958. A zoogeographical study of the amphibians and reptiles of eastern Canada. National Museum of Canada. Ottawa, Ontario. Bulletin 155: 1-119.

Cook, F. R. 1967. An analysis of the herpetofauna of Prince Edward Island. National Museum of Canada. Ottawa, Ontario. Bulletin 212. Biological Series Number 75.

Gilhen, J. 1984. Amphibians and reptiles of Nova Scotia. Nova Scotia Museum. Halifax. 162 pages.

Gilhen, J. 2000. Amphibians and reptiles of Nova Scotia: Species recorded in the accession books of Harry Piers 1899-1939. Unpublished report. Nova Scotia Museum, Halifax, Nova Scotia. 162 pages.

Gilpin, J. B. 1875. On the serpents of Nova Scotia. Transactions of the Nova Scotia Institute of Science 4: 80-88.

Jones, J. M. 1865. Contributions to the natural history of Nova Scotia: Reptilia. Transactions of the Nova Scotia Institute of Science I(iii): 114-128.

Klauber, L. M. 1972. Rattlesnakes: Their Habits, Life Histories, and Influence on Mankind. Second edition. Volume 1. Published for the Zoological Society of San Diego by the University of California Press, Berkeley and Los Angeles, California.

Peters, J. A. 1964. Dictionary of Herpetology. Hafner Publishing Company, New York, New York.

Rowell, J. C. 2012. The Snakes of Ontario: Natural History, Distribution and Status. Privately Printed. $411+$ vi pages.

Received 27 September 2013

Accepted 18 November 2013 